\title{
The Beast Initiate: The Lycanthropy of Heracles
}

\author{
By Carl Anton Paul Ruck*
}

The obscurantist Hellenistic poet Lycophron referenced the initiation of Heracles as a beast suckling the breast of the goddess Hera. This was the event that was the mythological origin of the Galaxy and of the lily flower that incarnated the same deifying essence as the celestial milk of the goddess and it was the etiology for the domestication of felines. As the Lion of Nemea, Heracles was the greatest of the wild cats. The lily was an analogue of a sacred mushroom, as the narkissos of Persephone's abduction by Hades. The event of the lactation of Heracles is depicted on four Etruscan mirrors and a Faliscan-Hellenic red-figure krater. The deifying milk-flower of the goddess was a ritual of adoption into the family of the celestial deities, that Hera performed also with two other bastard sons of Zeus, Hermes and Dionysus. As the beast being initiated, Heracles became a wolf. Like the motif of the domestication of the cat, the lycanthropy of Heracles involves the whole family of canines, from the domesticated dog to its wilder antecedents in the wolf and its analogue as the fox. The lycanthropy initiation is a bacchanalian rite of rootcutters and is a motif of warrior brotherhood widespread among the Indo-European peoples.

\section{Milk-Flower}

The etiological myth for the domestication of the cat is the tale of the metamorphosis of the handmaiden Galanthis, named as "Milk -flower," extant in various degrees of completeness in three ancient literary sources and depicted as the breastfeeding of Hercules on four Etruscan mirrors and a Faliscan- Hellenic red-figure krater, with significant variations that testify to an underlying theological complex implicating the lily as the milk-flower of the celestial Galaxy and an analogue of a psychoactive mushroom, bacchanalian root-cutting rituals, and the visionary sacrament of ancient Mystery religions.

Ovid narrated the event in the Metamorphoses. ${ }^{1}$ Ovid's context for the tale is typically playful and ironic, the womanly chat of Alcmene with Iole, the pregnant wife of her grandson Hyllus. In the narration, Alcmene recalls her own pregnancy with the infant Heracles and hopes that Iole has an easier delivery.

When Alcmene was in labor, Hera (Juno), the wife of Zeus (Jupiter) had sent the goddess of childbirth to sit upon the altar beside the birthing chamber with her legs crossed and fingers interlocked to compress and seal the avenue of delivery. Galanthis, her slave girl of the common people (media de plebe), concerned for her mistress now suffering the seventh day of her agony played a trick. She rushed in and falsely proclaimed a successful delivery. ${ }^{2}$

*Professor of Classics, Boston University, USA.

1. Ovid, Metamorphoses, 9. 273 et seq.

2. Ovid, Metamorphoses, 9.311-312. 
Congratulate the mistress. Alcmene of Argos is delivered of her burden. She's the mother of a boy, the answer to her prayers.

The startled goddess deceived unclasped her legs, and the infant passed through.

Galanthis laughed at her clever trick and ridiculed the cheated goddess, angering her so that she grasped the poor maidservant by her blond-red hair and dragged her upon the ground, transforming her arms into forelegs. Ovid challenges his reader to know the manner of the metamorphosis, not naming the cat, but only saying that since she had aided the woman in parturition with her lying mouth, that's how she would give birth, through the mouth, and just as before she had come and gone from the house, that's how she would continue, ${ }^{3}$ indicating that she was henceforth a domesticated animal, a lowly commoner admitted into the house of her mistress. Delivery through the mouth or the word encodes the secret of a Mystery religion, and the clever Galanthis is comparable to the dwarfish Iambe-Baubo of Eleusis.

Several centuries later, the Greek grammarian Antoninus Liberalis offered a prose summary of the tale of the maidservant's metamorphosis. His version derived the tale from a lost verse epic, the Heteroeumena ("Metamorphoses, Changes") of the second-century BCE Hellenistic Greek Nicander, a hereditary priest of Apollo in the court of the kingdom of Pergamum, one of the inheritors of the conquest of Alexander the Great. Nicander's extant poems, the Alexipharmaca and the Theriaca indicate his vast knowledge of toxins derived from plant and animal sources, probably an expertise acquired from his training in priestly lore. The version summarized by Antoninus Liberalis (Metamorphoses, 29) is probably closer to Nicander than Ovid. The name of the maiden is Galinthias, a variant of the same Milk-flower, and she is not a commoner or slave girl, but Alcmene's childhood playmate and the daughter of the Theban Proetus, the legendary eponym of one of the city's famed seven gates. The Fates or Moerae who attended the forestalled birthing changed the girl into the cat, an animal that was thought to conceive via the ear (a detail not mentioned by Ovid) and deliver via the mouth. The goddess Hecate took pity of her and made her one of her sacred animals, along with the dog. Heracles when he grew to manhood dedicated a sanctuary to her at Thebes.

The obscurantist Hellenistic poet Lycophron referenced the initiation of Heracles as a beast suckling the breast of the goddess Hera (thér mystes): ${ }^{4}$

[Phemios' son, i.e. Theseus] went with the beast initiate who sucked the ample breast of the hostile goddess Tropaia ["who grants victory," Hera], [Theseus] who stole the menstrual belt....

Phemios as the father of Theseus is unattested elsewhere, but the twelfthcentury Byzantine grammarian who wrote the Suda records that Phemios was the

\footnotetext{
3. Ovid, Metamorphoses, 9.322-323.

4. Lycophron, Alexandra, 1327-1328.
} 
father of Aegeus and hence the grandfather of Theseus. Such is the erudite riddling obscurity of Lycophron's poem.

The first-second-century CE Greek Christian anti-Semitic epistle attributed to Barnabas, in listing animals taboo for eating, condemns the cat as hateful to the Lord for its manner of procreation, making the mouth, however, the organ of unlawful sexual congress, apparently a condemnation of oral sex. ${ }^{5}$ This confusion entered the medieval bestiary tradition, which makes either the ear or the mouth the equivalent of the vulva. ${ }^{6}$ This perverts the obvious symbolism of the tale, that the spoken word heard (ear) opens the way for delivery (mouth), the riddling formula for a mystical revelation or Mystery initiation.

Pausanias mentioned the sanctuary that Heracles dedicated in his description of the city in the second century CE. ${ }^{7}$ In view of the name of Milk-flower, it is significant that the females who were impeding the opening of the birth channel are not named as the goddess of birthing or her analogues, but, according to the local Theban tradition reported by Pausanias, they were a sisterhood of pharmaceutical sorceresses (Pharmacides) sent by Hera, and Galanthis/Galinthias may be one of them, since she is cited as a daughter of the legendary seer Tiresias, perhaps the spiritual daughter as an initiate, since her name is not cited as the Milk-flower Galanthis or Galinthias, but Historis, the "person who knows," cognate with "wisdom" and hence "witch." In the Greek language, wisdom etymologically results from the visionary experience of sight. Historis is the equivalent of a Spanish sabia and curandera, a shaman. The Theban sanctuary had a statue of her as Galanthis. ${ }^{8}$

Thus, the cat was personified as the sorceress Gale, a dealer in spells, whom Hecate metamorphosed into a cat. ${ }^{9}$ The "cat" (galée, galé) was named for its fondness for "milk" (gála, gálaktos, cognate with Latin lac, lactis). The cat, even in antiquity, was noted for the acuity of its vision, especially sight in the darkness of night, and for its lustful estrus. "Cat" was slang in Greek for a girl. ${ }^{10}$ As with the canines (dog, fox, and wolf), the felines (panther, leopard, and lion), are all versions of the various species of cat in mythical tradition, segregated merely into stages in the evolution from wild to potentially domesticated home pets or helpmates.

Both the dog and the cat were less tamed in Classical antiquity and not sentimentalized, but tolerated for their assistance, the dog as guardian and in hunting, herding, and warfare, and the cat as a predator on rodents and snakes. Isidore of Seville (seventh century CE) called it a "mouser" (musio) and derived "cat" from captus ("caught") or catus ("acute" sight). ${ }^{11}$ The cat was also called aílouros in Greek, of uncertain etymology, but plausibly, at least as folk etymology, derived from aiolos ("fast-moving, nimble") and oura ("tail").

\footnotetext{
5. Epistle of Barnabas, 10.8 .

6. Thirteenth-century Aberdeen Bestiary, folio 23v.

7. Pausanias, 9.11.3.

8. Maurizio Bettini, Women and Weasels: Mythologies of Birth in Ancient Greece and Rome, trans. Emlyn Eisenach (Chicago: University of Chicago Press, 2013), 44.

9. Aelian (third century CE), On the Nature of Animals, 15.11.

10. Aristophanes, Wasps, 1185.

11. Isidore of Seville, Etymologies, 12.2.38.
} 
The Greek cat was a Mustelidae (ferret, marten, or polecat, which includes also skunk, mink, etc.). The modern domesticated cat (Felidae) evolved from a Numidian breed, first appearing in the first century CE as catta and in Byzantine Greek in the fourth century as katta, replacing Latin feles (of uncertain etymology) in Europe by the eighth century, Modern Greek gata, derived from Berber kaddiska.

\section{Herbalism}

After Alcmene's delivery, the Milk-flower cat maiden as one of the sorceress sisters took the infant Heracles to Mount Cithaeron outside of Thebes and tricked Hera into nursing him. The sisterhoods of pharmaceutical herbalist Pharmacides were not unique to Thebes. The prototypic exemplar of the motif was the abduction of Persephone by Hades from a sisterhood of flower-gathering sea nymphs when she plucked the narcotic nárkissos bloom, ${ }^{12}$ the etiological myth for the Eleusinian Mystery religion. ${ }^{13}$ These sorceress women were performing a Dionysian ritual. They were versions of the maenads or bacchants. Among the metaphors that describe their ritual, the bacchants impersonated wet nurses (tithénai) of the infant deity. ${ }^{14}$ The milk from their breasts, however, was not ordinary milk, but a divinizing potion. ${ }^{15}$

These metaphors represent the fantasies or ritual impersonations of rootcutters (rhizótomoi) or herb-gatherers. Thus, the emblem of their bacchanalian ritual was the thyrsus, the stalk of the giant fennel (Ferula communis), which was the symbolic container for the herbs gathered. ${ }^{16}$ It was also called the narthex, which has the obvious etymology (narco-thex) of a "narcotic repository." Nárthex was used as the title of various compendia of herbal medicines in antiquity. ${ }^{17}$

The thyrsus was a staff of altered mystical vision and emblematic of the psychoactive and magical herbs it contained. Prime among these were mushrooms, specifically, the psychoactive Amanita muscaria or fly agaric mushroom and related species so frequently involved in the folkloric traditions of later Europe. In common Latin culinary nomenclature, the stipe of the mushroom was called its thyrsus. ${ }^{18}$ Thus, the mushroom itself was the prototype of the herb gatherer's narthex, since the psychoactive toxins of the Amanita species are confined mainly to the rind of its cap, which represents the magical plants gathered into its receptive stalk, botanically termed its stipe or trunk, hence metaphorically a tree. In depictions and literary descriptions of the narthex, these plucked herbs are represented as ivy, bryony (wild squirting

12. Homeric Hymn to Demeter (2).

13. R. Gordon Wasson, Albert Hofmann, and Carl A.P. Ruck, The Road to Eleusis: Unveiling the Secret of the Mysteries (New York: Harcourt Brace, 1978), 85-136.

14. Homer, Iliad, 6.132.

15. Nonnus, Dionysiaca, 45.298-303: the milk is described as an "unfamiliar dew" (anéthes eérse), something a three-year-old had never tasted from his mother.

16. Theophrastus, Historia plantarum, 9.16.2.

17. Galen, 12.398, 959; Aëtius, 8.45.

18. Apicius, De re culinaria, third-fourth-century CE Latin cookbook, 7.15.6. 
cucumber), and smilax (bindweed, wild morning glory), all involved in traditions of mind-altering potential and as berried vines resembling the grapevine, but toxic in their natural state, whereas the leaves and berries of the grapevine are edible, but through the controlled fungal growth of fermentation capable of yielding a cultivated intoxicant, opposed to the natural toxicity of the wild vines. ${ }^{19}$ A Roman period Greek mythographer attributed the madness to their "grazing like animals" (nemonto, the equivalent of Latin pascuntur) on ivy, smilax, and laurel. ${ }^{20}$

The plants atop the thyrsus can be replaced by a pinecone, an emblem of the god, but also suggestive of altered vision, since the pineal gland was so named for its resemblance to the pinecone and commonly considered the visionary organ of mystical transcendence. $^{21}$

\section{Origin of the Milky Way}

As Hera suckled Heracles, he drank so voraciously that some of the milk scattered to the heavens, becoming the Milky Way or Galaxy. What fell to the earth sprouted as the lily (leírion). It can designate any of several species of herbaceous flowers which may or may not resemble the genus Lilium and which are not closely related to it or each other. In heraldry, it became the fleur-de-lis.

A gold signet ring from Cretan Isopata depicts a sisterhood of barebreasted priestesses with the heads of bees, with the milk of their breasts flowing to the Galaxy, in a ritual of plant-gathering that accesses a visionary experience, as indicated by the single disembodied eye and the epiphany of a deity floating in the sky. The bee was thought to derive both the inspiring drink of honey and the toxins of its sting from the nectar of the flowers it visited. The toxins of serpents and plants were similarly analogous, the serpent acquiring its poison supposedly by ingesting toxic plants, and plants becoming poisonous by growing in proximity to serpents. In Euripides' Bacchae (405 BCE, performed posthumously), the maenads scratch the earth with their fingertips and milk flowed like a swarm of bees, while from the ivy leaves of the thyrsus dripped down streams of honey.

Four flowers in the depiction on the signet ring sprout from the ground, perhaps single lily blossoms, with extended stamens and pistil, the nárkissos of Persephone's abduction. A wavy line separating the priestesses from the goddess terminates in a celestial "heart-shaped" ampule or vessel, as container for the elixir of the gathered plants or the lactation from their breasts. This may the earliest proto-Greek depiction, dateable to the mid second millennium, of the conjunction of the lilies with the milk of the Galaxy. A second, shorter wavy line flows from the breast of the central female on the ring, who is dancing directly above the largest of the four lilies depicted, four being also the number of the females in

19. Carl A.P. Ruck, (ed.), Dionysus in Thrace: Ancient Entheogenic Themes in the Mythology and Archaeology of Northern Greece, Bulgaria, and Turkey (Berkeley: Regent Press, 2017).

20 Antoninus Liberalis, Metamorphoses, 10.

21. Galen, De usu partium, 8.14. 
the dancing group, apart from the epiphany of the much smaller female in the heavens, spatially balancing the disembodied eye.

Another account of the origin of the Galaxy claimed that the milk was Rhea's, the mother of Zeus. It flowed when she pressed to her breast the "stone" that she gave Cronus to eat, disguised in swaddling as her infant son. The flowing milk that nursed the stone was Rhea's ruse to prove the authenticity of the stone wrapped in swaddling as indeed the divine infant in disguise.

\section{Ritual of Adoption}

A similar tale of Hera's nursing of Heracles was told about Dionysus and Hermes, both like Heracles, deified bastard sons of Zeus. The suckling of these sons of Zeus represents an acknowledged ritual of adoption in Greek and Roman culture. Plutarch described it, as prescribed by the Delphic oracle, as the procedure required to reintegrate among the living a man presumed dead: he must put himself in the women's hands, be washed and wrapped in swaddling, and then suck the breast, in the same manner as when he was newly born. Thus, his identity among the living was reestablished by being born anew. Diodorus Siculus similarly described Hera's nursing as a mimesis of birthing her adopted son as an adult:

Hera lay upon a bed, and drawing Heracles close to her body then let him fall through her garments to the ground, imitating in this way the actual birth; and this ceremony is observed to this day by the barbarians whenever they wish to adopt a son.

It is still practiced today as validation of artificial kinship, with the adult nursed by the tribal matron as a baby.

In suckling someone else's nursling, Hera is enacting her ornithological analogue as the cuckoo bird, which she bore traditionally upon her scepter, or ornamenting her throne. The scepter could also have the lily flower as its finial, sometimes ornamented with a floral motif to indicate its botanical reference. The two emblems recall the episodes of Hera's adoptive divinizing role as wet nurse with the milk of the Galaxy. Cuckoos were recognized in antiquity as brood parasites, laying their eggs in the nest of another species, leaving the foster parents to hatch their young, which is the etymology of "cuckoldry."

\section{The Lily-stone}

The so-called Suckling Painter depicted Hera with an ample exposed breast nursing Heracles as an episode of herbalism with the lily equated to a "stone." The artist is named for the fourth-century lekythos vase from southern Italy, now in the collection of the British Museum. The vase probably survived intact because it was sequestered in a tomb, and it can be expected to represent a scene of cultic significance for the deceased. 
Heracles is unmistakably not an infant, but an adolescent. This is true of all other surviving depictions of this episode. He is never an infant, but a pubescent youth. On the lekythos, Heracles is nude, except for bracelets, shoulder strap, and anklets. He is making direct eye contact with the goddess. In front of the nursing Hera stands Athena, identified by her aegis goatskin, which she is not wearing as usual as a shawl, but draped over her extended arm, holding in her hand a large flower that she has plucked. Athena holds the flower next to the suckling Heracles, equating the flower with the milk of the goddess, from which it presumably has sprouted and which she now has picked. It resembles the single trumpet-shaped blossom of a lily (leírion, krínon), as depicted on Minoan vases and frescos and the Isopatra ring.

Behind the seated Hera is the winged Iris, standing, the messenger goddess of the Olympians, probably signifying that this event fulfills the intention of Zeus. As messenger, Iris fulfills the same office as Hermes, but in her materialization as the rainbow, she visually signifies the linkage of the celestial and terrestrial realms. She holds a knobby staff, not a customary item of her iconography, but probably a depiction of the pruned olive club that will serve as the badge of Heracles' heroism, wielded in the labors that will win him admittance as a deity among the Olympian family. It is the traditional motif of the entheogen transmuted into the olive as the paramount triumph of cultivation. She is looking down at Heracles' mother Alcmene, who is seated and holding a victor's wreath. Above her is a window, recalling the deceptive visit to her bedchamber, in which Zeus had impersonated her husband Amphitryon. On the other side, behind Athena, is Aphrodite, seated high upon a rock and identified by jewelry and the mirror she holds. Below her is a myrtle tree, which was emblematic of the vulva. On a higher level appears Eros, wings spread and looking down at his mother, a wreath over his right shoulder, holding another wreath in his right hand and an embroidered tainía fillet or headband in his left. Like wreathes, the headband was an award of victory. A tainía was meant to be tied, and especially when wielded in the hand of Eros, it had erotic connotation of union, not only sexual, but metaphysical with a spiritual lover in another trans-dimensional realm.

In a scene depicted with such detail, with different types of footwear, jewelry and items of clothing distinguished by style and ornamented with fabric design, it would be remiss not to notice four round objects on the ground, which is where a plant, like the lily that Athena has picked, could be expected to appear. They are not lilies. They are spherical like stones.

\section{Celestial Circlet}

A late fourth-century BCE Etruscan mirror from Volterra depicts Uni (Hera/Juno, i.e. [Y]uni) suckling Hercle (Heracles). ${ }^{22}$ Like the lekythos vases, mirrors were tomb dedications. The Etruscan mirrors were expensive objects indicative of a woman's status in life, and beyond their use while living, they

22. Etruscan mirror, from Volterra, late fourth century BCE, Uni (Hera) nursing the grown Heracle, Museo Archeologico Nazionale, Florence. 
were placed in the tomb to transfer that status to the afterworld and often had depictions relevant to the preparation for immortality. ${ }^{23}$

On the mirror, Heracles is seen not as an infant nor an adolescent, but as a muscular and bearded adult man, leaning on his club as he suckles upon the teat that a very beautiful Uni has exposed and holds for him. Uni sits on an elaborate throne, with footstool, suggesting that the locale is Olympus. The scene on the mirror is witnessed by Olympians (a nude Apollo / Apulu, identified by laurel chaplet and staff of branching laurel; two nude females, wearing elaborate necklaces; one, distinguished by the uncovered bridal veil, is probably Hebe ("Eternal Youth"), who will become Heracles' Olympian wife; and a very handsome and regally robed Zeus/Tinia (cognate with Zeus as Dios), identified by his scepter. It is a ritual of formal adoption into the celestial family, and labeled in Etruscan with a placard held by Tinia, that reads, perhaps: "This image shows how Hercle, Hera's son, drank milk," or something similar, since Etruscan is only partially decipherable. ${ }^{24}$

A bald and bearded satyr with a bizarrely disjointed neck reclines above them. The satyr is using the saucer as a mirror for divination by lecanomancy (divination by inspection of a reflecting liquid in a "basin" lekané), hence the presence of Apulu as prophetic deity, with the top of his psychoactive oracular laurel directly below the phiale libation saucer. A winged nude child on the handle of the mirror, wearing only a ring-circlet on a ribbon as necklace, is Epiur, holding an oval egglike object in either hand as symbolic of rebirth or perhaps as sortes (lots) for divination. Epiur (Greek epiouros) was the guardian spirit of infants.

The figure of Tinia/Zeus on this mirror has sometimes been identified as Poseidon/Neptune based on his scepter, which could be interpreted as a trident, but the three tines of the fork are too small and the outer two are curled outward, making it not serviceable as a fishing prong. The central tine is flanked by two additional tines curled inward. The scepter's finial is clearly a stylized lily, with central pistil and surrounding stamens. Thus, perhaps we should interpret the winged child as holding "stones" instead of sortes and the circlet, worn as an ornament on his necklace, as emblematic of the circle formed by the Galaxy in the heavens.

\section{Lycanthropy}

A mirror from Tarquinia (ca. 300 BCE) depicts the scene of the suckling with the seated Uni attended by a woman standing behind and grasping her, who is perhaps supporting her as midwife, although Hercle is fully adult, but breadless, with a bizarrely drawn face, with what appears to be more like a snout than a nose, and supporting himself with his club. ${ }^{25}$ This is a scene of adoption through mimetic birthing. The lower drapery of Uni's gown has been pulled up into her lap

23. Nancy de Grummond, "The Etruscan Mirror," Notes in the History of Art 4, no. 2/3 (1985): 26-35.

24. Eca sren tva ichnac hercle unial clan thra sce.

25. Tarquinia, Museo Archeologico Nazionale, Florence. 
to suggest that Hercle has emerged from between her legs. Behind the midwife is a very tall flower, identifiable perhaps as the lily, complete with leaves, long stems, and two buds, very carefully drawn, although the figures of the personae are rather ineptly portrayed, especially the weird face of Hercle, who appears somewhat canine, making the presence of the carefully delineated lily more remarkable.

The winged female behind Hercle is perhaps Mean, Athena as the Victory goddess Nike, with proffered crown. Behind Hercle, directly beneath the proffered crown, is another circlet, much larger, like an oval shield, but it obviously belongs neither to Mean nor to Hercle, who traditionally doesn't wield a shield in his feats of heroism. The circlet apparently is being carried in the talons of a small bird, perhaps a dove, above it. The dove may identify the winged goddess not as Mean, but Turan, the Etruscan equivalent of Venus. Her name is pre-Hellenic, cognate with tyrannos, as "mistress," and may be the Etruscan word for "dove" or "swan." She was both mother and lover, and signified health and vitality, hence the equivalent of Hebe as Hercle's bride on the mirror from Volterra. Turan, like Hebe, is the Etruscan empowering female for the male's sovereignty.

The circlet, however, isn't an empty ring; it is filled with three lateral wavy lines that identify it as the Milky Way. The circlet of the Milky Way carried in the talons of the dove on the left balances the lily on the right and is intended to equate the two items, in accordance with the description of the Galaxy as a somewhat circular figure or "ring" among the constellations, ${ }^{26}$ a "ring, although not perfect" (deformatum, "deformed"), ${ }^{27}$ or as depicted on the Etruscan mirror, oval shaped.

The weirdly lycanthropic snout of Hercle may have been the intention of the artist. In the same manner, the uncharacteristic unmuscular body and arm of the hero and the canine leg and foot were probably intentional. Etruscan artists excelled in the depiction of humans, and mirrors were objects of considerable cost. Hercle, as the artist intended, is metamorphosing into a wolf, accessed via the deifying milk from Uni's breast and its equivalent, the oval circlet of the Galaxy borne in the talons of the empowering dove. This is the significance of Lycophron's riddling bizarre reference to Hercules in this episode as a theriomorphic "bestial initiate" (ther mystes). ${ }^{28}$

The lycanthropy of Heracles is the major motif in Euripides' Heracles tragedy (ca. $416 \mathrm{BCE}){ }^{29} \mathrm{He}$ has just fetched the infernal hound Cerberus from Hades. In his absence, the "Wolf" Lykos intends to kill Heracles' family. Hercules intervenes to rescue them, but at the critical moment, Lyssa, the goddess of madness, commanded by Hera, drives her pack of hounds against him, infecting him with the toxin of his own arrows, and he becomes mad. Thinking that he is performing one more of his heroic labors, in a delusion of altered consciousness, he murders his wife and children. He becomes the "Wolf." Lyssa, the agency for the delusion, is named as the "She-wolf," the personification of rabidity, the madness that regresses the domestication of the canines back to its lupine predecessor. She was costumed with a wolf headgear, the fox pelt headdress of the

26. Pseudo-Hyginus, Astronomica, 2.43.

27. Pseudo-Hyginus, Astronomica, 2.43.

28. Lycophron, Alexandra, 1327-1328.

29. Carl A.P. Ruck, "Duality and the Madness of Herakles," Arethusa 9 (1973): 153-176. 
Thracian maenads. The toxin associated with Cerberus was Aconitum lycoctonum, commonly called wolfs-bane, a plant of the Delphinium family, of which all species are toxic. Heracles was costumed for the play with his traditional feline headgear, the Nemean lion-skin, and a verse in the text suggests that Lykos, like Lyssa, was costumed with a canine headdress.

The Alexandra was ascribed to the third-century BCE tragedian Lycophron, although perhaps falsely. Lycophron was his adopted name. It means "with the mind of a wolf," and it suggests that he had himself been a theriomorphic initiate into the lycanthropic Mysteries in Southern Italy, the home of his so-called adoptive father.

The lycanthropic metamorphosis would have special significance for the Etruscan/Romans The mythical founders of Rome were sons of Mars, nursed as infants by a wolf, ${ }^{30}$ which suggests the cult of warrior lycanthropy, ${ }^{31}$ although some accounts rationalized her as a woman, "wolf" (lupa) being slang for a prostitute. $^{32}$

\section{Galaxy-stone}

The word for "stone" (lás, láos) offers a traditional pun with the word for "people" (laós), documented as early as the Homeric tradition, ${ }^{33}$ and demonstrated in the myth of Deucalion, who created people from the stones that were the bones of mother Earth. ${ }^{34}$ These are the primordial creatures, the "stones" that sprouted as mushrooms after a fall of rain at Corinth: $:^{35}$

Here, tradition says, that in earliest times, human bodies sprang from fungi swollen with rain.

Theophrastus records that certain mushrooms sprouting near the sea petrify to stones with the heat of the sun. ${ }^{36}$ "Stone" is a metaphor for mushroom as a folkloric motif, documented by a Byzantine commentator on the second- century BCE Nicander. ${ }^{37}$

30. The earliest account is Dionysius of Halicarnassus (first BCE), Roman Antiquities, 1.7779, derived from the third-century BCE Quintus Fabius Pictor.

31. Kris Kershaw, The One-eyed God: Odin and the (Indo-)Germanic Männerbünde. (Washington, D.C.: Journal of Indo-European Studies, Monograph No. 36, 2000); Carl A.P. Ruck, "The Wolves of War: Evidence of an Ancient Cult of Warrior Lycanthropy," Neuroquantology 14, no. 3 (2016): 544-566.

32. Livy, 1.4.7.

33. Hesiod, Catalogue of Women, frag, 82 (Strabo, 7.322): "So out of stones moral men were made, and they were called people." Homer, Iliad, 24.611.

34. Ovid, Metamorphoses, 1.393-394.

35. Ovid, Metamorphoses, 7.392-393.

36. Theophrastus, Historia plantarum, 4.7.2. John Marco Allegro, The Sacred Mushroom and the Cross: A Study of the Nature and Origins of Christianity within the Fertility Cults of the Ancient Near East (London: Hodder and Stoughton, Ltd, 1970), chap. 6, footnote 13.

37. Scholia to Nicander, Alexipharmaca, 526. The note comments on Nicander: "For to different kinds of mushrooms different names have been assigned. " 
As something sacred, mushrooms have no name, only metaphors. The paucity of metaphors reflects a taboo against profane use, shrouding them with phobias of lethal toxicity. Thus, in English there are only four words for the mushroom. It can be called a fungus, which is safe because it is a foreign and quasi-scientific assimilation from Latin, but fungus itself is a metaphor, cognate with the Greek spongos for "sponge," descriptive of the mushroom's rapid fruiting, expanding as it absorbs the moisture of a rainfall. Transculturally, the genesis of mushrooms is attributed to the thunderbolt, encapsulating its celestial fire in the expanding wetness of matter. ${ }^{38}$ The sponge itself is interchangeable with an aquatic rock. The blood from the decapitated head of the Gorgon Medusa fell to the ground as coral, ${ }^{39}$ which was so named in Greek as the "little pubescent girl" (korállion), equating the blood with menses. It was pliant, but changed to the hardness of rock when submerged in water. Ovid's extended narration of the event indicates that his audience understood his mythological reference. Pliny called it the Gorgonstone. $^{40}$ The Gorgon Medusa herself was a zoomorphism of the mushroom, as depicted on a fourth-century BCE Greek vase, ${ }^{41}$ and substantiated by the local mythological tradition that Pausanias records about Mycenae, whose name (Mykenai) was given the etymology of the "Mushroom-sisterhood" of the Gorgons. ${ }^{42}$ This is probably a verbal punning calque of its pre-Indo-European name as the Minoan sisterhood of the Mekonai, the sisterhood of the poppy flower. ${ }^{43}$ The earliest record of the city's name as $m-w-k-i-n-u$ (Mukina) occurs in an inscription from the mortuary tomb of Pharaoh Amenhotep III, the father of Akhenaten, at Kom el-Hettân (1349 BCE). The opium capsule is often depicted in Minoan iconography as a knob on a stem, resembling a mushroom. The capsule also resembles the pomegranate, which often has a prominent elongated calyx, and when inverted presents the likeness of a mushroom. The bloody matrix of the pomegranate (which was called rhoie or "flux") would suggest the menses of the coral, as well as any knob-shaped item, ${ }^{44}$ like the mykos.

The mushroom in English can also be called champignon, which is similarly distanced as foreign, assimilated from the French and naming it simply as something native to the "fields" (champs), technically specific for the button mushroom (Agaricus bisporus) native to the grasslands, the commonly cultivated mushroom.

38. R. Gordon Wasson, Stella Kramrish, Jonathan Ott, and Carl A.P. Ruck Persephone's Quest: Entheogens and the Origins of Religion (New Haven: Yale University Press, 1995), 83-94; Carl A.P. Ruck, "Mushroom Sacraments in the Cults of Early Europe," NeuroQuantology 14, no. 1 (2016): 68-93.

39. Ovid, Metamorphoses, 4.735-752.

40. Pliny, Natural History, 37.56.

41. Fourth-century BCE amphora, Berlin, inv. no. F. 3022.

42. Pausanias, 2.16.3.

43. Ruck, The Son Conceived in Drunkenness, 140-141. Michael Ripinsky-Naxon, The Nature of Shamanism: Substance and Function of a Religious Metaphor (Albany: State University of New York Press, 1993), 159.

44. Herodotus, 7.41. 
The term "toadstool" is a folkloric metaphor identifying it as a stool for a toad, ${ }^{45}$ which is frequently associated with the mushroom because of its secretion of psychoactive bufotoxins like the psilocin of Psilocybe mushrooms. The toxin in the psychoactive Amanitas is primarily muscimol (a $\mathrm{GABA}_{\mathrm{A}}$ receptor), not the same as psilocybin (which is like LSD, mescaline, and DMT). The toadstool is specifically a toxic mushroom, but commonly applied to all fungi as loathsome and dangerous. In Elizabethan folklore, the toad absorbed its venom by lurking under so-called stones. ${ }^{46}$ This is analogous to the ancient tradition that the toxin of serpents and plants as reciprocal, each deriving the toxin from the other. In French, the Amanita muscaria is specifically called crapaudin, from the "toad" (crapaud). The mushroom as a stool is transcultural, occurring in the effigy of the Aztec analogue of Dionysus as Xochipilli, seated upon a stool ornamented with glyphs for the psychoactive mushroom. ${ }^{47}$

The scientific myco-prefix as in "mycology" is a Greek metaphor designating the mushroom as something mucous, repulsively slimy with bodily effluents like semen and menses. ${ }^{48}$ The Greek amanites ${ }^{49}$ (Modern Greek manitari, botanical Latin amanita) probably derives from the Egyptian amentet for the otherworld, assimilated into Greek in the Ptolemaic period, and personified as the goddess Amentet, equated with the Greek Persephone.

The only common term as a mushroom is similarly a folkloric metaphor designating it as an onomatopoeic bovine zoomorphism, assimilated from the French mousseron, derived from Late Latin mussare, "to bellow or moo," cognate with Greek muá-ein. The same root is responsible for the Greek muía (diminutive muíska) and Latin musca for the fly as onomatopoetically "buzzing." Mushrooms bellowed as they fruited from the earth. ${ }^{50}$ In the myth of Zeus and his courtship of the cow-maiden Io, the bellowing was the mooing of the cow in estrus, stung with the toxin of the cow-fly (Tabanus bovinus), which was called oistros, assimilated into English as estrus, the entomological ghostly metamorphosis of her former tender Argos, who wielded the cow-prod and whip of sexual arousal. ${ }^{51}$ The Latin version of the cow-prod is the stimulus, which Virgil employs in his description of Amata, the "beloved," whipped into estrus by the Fury Alecto with the toxins of Mycenae. ${ }^{52}$ The multiple eyes of the Argos Panoptes were placed in the tail of the peacock, whose feathered sexual display is triggered by the pheromone of its

45. Valentina Pavlovna Wasson and R. Gordon Wasson, Mushrooms, Russia, and History (New York: Pantheon Books, 1957), 65-91.

46. Shakespeare, Macbeth, act 4, scene 1, verse 6-8: Toad that under cold stone days and nights has thirty-one sweltered venom sleeping got.

47. R. Gordon Wasson, The Wondrous Mushroom: Mycolatry in Mesoamerica (New York: McGraw-Hill, 1980), 57-78.

48. Carl A.P. Ruck, "The Great God Sabazios and the Crab Dance in Athens," in The Stone Mushrooms of Thrace (Alexandroupoli: EKATAIOS, 2012), 193-220.

49. Nicander, frag. 79.

50. Aristias, (fifth-century BCE tragedian) frag. 6 (Nauck), probably from his Perseus tragedy; Ruck. Dionysus in Thrace, 49-51.

51. Ruck, Dionysus in Thrace, 51-52.

52. Vergil, Aeneid, 7.346 et seq. 
peahen, the iconic bird of Hera as wife of Zeus. ${ }^{53}$ The multiple "eyes" of the herdsman and the stinging fly suggest the scabby white remnants of the shattered universal veil that adhere to the cap of the Amanita muscaria and related psychoactive species, an "eye" being an appropriate metaphor for a mushroom that affords access to visionary experience. The cow-maiden in estrus pursued by her herdsman fly is an expression of this mushroom's common association with the fly; hence its specific nomenclature as muscaria. Flies are attracted to this mushroom to lay their eggs in its cap, and within a few days, the mushroom is loathsome, crawling with larvae, but also emblematic of rebirth, since souls were commonly depicted as entomological manifestations, like bees and butterflies. Folkloric tradition equates all flying insects with the same symbolism. ${ }^{54}$ The flyagaric mushroom is naturally programmed with a scenario for initiatory rituals. It was commonly mixed with milk and employed as an insecticide attracting flies, who drowned in the galactic potion. ${ }^{55}$ Hence its name in French as tue-mouche.

Perhaps no plant masquerades more easily as a stone than the fungi (which have no leaves, branches, roots, or flower), for which the name is "stone" in Hebrew (PTR). The evangelist Matthew's account of the ordination of Simon with the new name of Peter (Greek pétros, "stone," pétra, "topographical rock") as the rock entrusted with the keys of heaven ${ }^{56}$ puns upon the mushroom. The ancient key was a knobbed bolt, presenting a likeness of a mushroom, opening the door to mystical experience. ${ }^{57}$ The Jewish name Simon designates "someone who listens," a suspiciously too apt name for the first apostle. His role as "head," Cephas (Greek képhas, kephalê), further puns upon Aramaic kepha for "stone," and the anthropomorphism of the mushroom as a harvested head, like the Gorgon Medusa. ${ }^{58}$ It should be remembered that the Gorgon head had the efficacy of petrification. The German Pilz for mushroom is derived from Btilz, an assimilation of the Latin boletus (Latin for "mushroom," cognate with Greek bolitos, a metaphor as "clod of earth, stone"), one of which Pilze is called Steinpilz, "stonemushroom." The tradition of the "stone" as the substance from which the deifying elixir is prepared is the fundamental motif of alchemy, termed the philosophers' stone (lapis philosophorum), first mentioned by Zozimos of Egyptian Panopolis ( $c$. $300 \mathrm{CE}$ ). The "stone" was edible. Drinking the elixir accessed enlightenment, gnosis, and the transcendent metamorphosis of the leaden soul to golden perfection.

Stones were thought to have magical powers. Gemology in antiquity was a compendium of traditional accounts, passed on without verification by each new author, and it often includes garbled information which derived from mythologized stones, which were not actual stones. The anonymous Orphic Lithica is a work of the fourth century CE. The narrative scenario that serves as

53. Carl A.P. Ruck, The Great Gods of Samothrace and the Cult of the Little People (Berkeley: Regent Press, 2017), 136 et seq.

54. Wasson and Wasson, Mushrooms, Russia, and History, 206.

55. Albertus Magnus (thirteenth century), De veg etalibus, 2.6.87. This is the first mention of the fly-agaric in Europe.

56. Matthew, 16.18.

57. Allegro, The Sacred Mushroom and the Cross, 47 et seq.

58. Allegro, The Sacred Mushroom and the Cross, 46-47. 
introduction indicates that the compendium is Orphic. It records a tradition about a galaxy-stone, whose antiquity goes back to before the time of Pliny. It dissolves in the mouth, tastes like milk, and affects the mind, depriving it of memory, and comes from Egypt. ${ }^{59}$ The Orphic Lithica lists the galaxy-stone as second in the hierarchy of magical gems, after only the crystal, which had pride of place for its ability to focus the rays of the sun and ignite fire. The galaxy-stone was filled with "divine milk" (thespésios gála) and had the property to alter even the mind of deity and bend it to one's will. ${ }^{60}$ Some people called it lethaion, because it induced amnesia in both men and gods. Lethaion suggests the Fountain of Lethe or "Forgetfulness," a river in the netherworld, of which Orphic initiates were instructed not to drink, however burning the thirst of their soul for the wetness of incarnation. "Truth" was a-letheía or the negation of forgetfulness, remembrance, recognition, recollection of previous incarnations, gnosis, knowledge. In Virgil's description of the river Lethe, which the author of the Lithica would well have known, innumerable souls fly about like bees, filling the grove with buzzing, as they settle into white lilies, harvesting their nectar, waiting for reincarnation, drinking of the stream's milky juice of oblivion. ${ }^{61}$ The juice-nectar of the lily is confounded with the waters of the river and the simile of the bees presents the souls as the prototypic root-cutters.

The galaxy-stone was filled with ichor, the fluid that flowed instead of blood in the veins of the immortal deities, which you could milk from it, as if it had udders, yielding a fluid just like milk in every respect. The white scabs of the Amanita muscaria are fantasied as udders of a cow. ${ }^{62}$ The galaxy-stone is a version of the Zoroastrian Persian haoma sacrament, which the Greeks knew as [h]ómomi, and it was associated with lycanthropy. ${ }^{63}$ Zoroaster was cited as the author of a compendium of gemology; several of the stones may masquerade as haoma. Pliny records one of these as much prized by the Magi, the astriotes, so named as a "star" apparently fallen from the Galaxy. ${ }^{64}$ The Avestan haoma is cognate with the Vedic Soma potion which was considered milk from the udders of the Celestial Cow of the Galaxy, and it is always concocted with cow milk, to implant this metaphor of lactation. It was churned into existence from a cosmic ocean of milk, the Galaxy. In the hagiographic biography of Zoroaster, his father mixed the haoma with milk and shared the drink with his wife to conceive the legendary eponymous founder of the lineage of astrological priestly prophets who perpetuated the title of Zoroaster or "star-gazer" and Magi. The probable date of Zoroaster is the mid second millennium BCE, but since it was a priestly title, he often is placed in the eighth century. Among the ethnically marginalized Yezidi,

59. Pliny, Natural History, 37.56.

60. Orphic Lithica, 191-203.

61. Vergil, Aeneid, 6.705-715.

62 Peter Lamborn Wilson, Ploughing the Clouds: The Search for Irish Soma (San Francisco:

City Lights, 1999), 31: "Púca" as a mushroom name also means "heifer's pouch" (udder).

63. Plutarch, De Iside et Osiride, 46 (369d-f).

64. Pliny, Natural History, 37.45. 
the Amanita muscaria is still employed today as haoma in the cult of Mithras. ${ }^{65}$ The Hindu dietary prohibition against mushrooms was probably extended to include all bovines as taboo. The Buddha broke the taboo by consuming mushrooms in his last meal, prepared for him by a blacksmith, as he journeyed to the pre-appointed site of his Great Demise with his entourage of monks, who were forbidden to partake of the tabooed meal. ${ }^{66}$ Surely, a blacksmith as implausible chef implies an alchemical diet.

The human breast itself could be likened to a spoked wheel, with the nipple as the axle or central hub. ${ }^{67}$ The episode is a hallucinatory account of Zeus's insemination of Semele as a serpent, bellowing like a bull. The spoked wheel (Greek [w]itus) is a glyph for the mushroom, depicting the radiating underside of its gilled cap. It is the etymology for the "vine" (Latin vitis, as in "viticulture") and of "wine" (Greek [w]oínos). ${ }^{68}$ As an Indo-European word imported into vinegrowing regions from their original northern homeland, where the climate is not suitable for the growing of grapes for fermentation, it must have been a word for their original "intoxicant," which was later applied for the intoxicant of wine as found in their new Mediterranean environment. This is an apt assimilation since the mushroom was termed a "fermentation of earth,"69 and the fungal yeasts manipulated in the process of fermentation were a civilizing taming of the wild, uncultivatable mushroom. A circle with a central dot is a glyph for the mushroom in indigenous Mesoamerican cultures, as is the "wheel," as a means of shamanic, whirling, dizzying transcendence or transport. The seer Ezekiel received his call to prophecy amid a thunderstorm with the mushrooms fruiting as the wheels of the mekabah chariot throne of Yahweh. ${ }^{70}$

Soma/haoma is related etymologically to the Greek hú-ein, "rain," with the connotations of "squeezing" out the water or juice, cognate in English with "suck", as in suckling or the manipulation of the elongated teats of the udder of the celestial cow, analogous to the masturbation of the bull, with the male's seminal ejaculate analogous to milk. ${ }^{71}$ The nymphs of Nysa nursed the infant Dionysus with "the milky juice" (glagóessan...ikmáda) of their breasts, ${ }^{72}$ and they were transformed into the constellation of the Hyades, ${ }^{73}$ not pressing their nipples to his mouth, but as droplets of rain falling from the Galaxy as the baby lay supine upon his back gazing up upon the stars. The Hyades were supposedly named for the

65. Carl A.P. Ruck, Mark Alwin Hoffman, and José Alfredo González Celdrán, Mushrooms, Myth, and Mithras: The Drug Cult that Civilized Europe (San Francisco: City Lights, 2011), 235238.

66. R. Gordon Wasson, "The Last Meal of the Buddha," in Persephone's Quest, 117-139.

67. Nonnus, Dionysiaca, 7.331.

68. Carl A.P. Ruck, "The Wild and the Cultivated: Wine in Euripides' Bacchae," in Persephone's Quest, 178-223. Pierre Chantraine, Dictionnaire étymologique de la langue grecque (Paris: Klincksieck,1968-2009), s.v. oinos and botrys. Hjalmar Frisk, Griechisches etymologisches Wörterbuch (Heidelberg Carl Winters, 1954-1970), s.v. oinos and botrys.

69. Nicander, Alexipharmaca, 521; cf. 525 with scholia.

70. Ezekiel, 1.1-28.

71. Aristophanes, Birds, 1646: "I will make you king and feed you on phallic bird's milk."

72. Nonnus, Dionysiaca, 9.31 .

73. Pseudo-Apollodorus, Bibiotheke, 3.4.3; Pherecydes, scholia to Homer, Iliad, 18.486; Pseudo-Hyginus, Astronomica, 2.21; Scholia to Germanicus, Aratea. 
"rain" (hú-ein), by the traditional etymology. By some accounts, the nursing occurred underground, with the infant hidden in a cave, a murky chamber, or a cellar. ${ }^{74}$ This suggests the metaphor of a spongey fungus awaiting the rainfall for the incarnation of the celestial fiery spirit from the lightning's bolt that traditionally is the generative cause for the fruiting of the mushroom. It was this incarnation that allowed the bacchants to draw milk from clods of earth or from rock as from living breasts. ${ }^{75}$

There was, however, another meaning to the name of the Hyades. The Hyades were also called Suculae or "suckling piglets" in Latin, which is the more plausible etymology for their Greek name, from hys for "pig." ${ }^{176}$ The significance of the pig is its association with the Goddess, being an obscene metaphor for the female genitals, ${ }^{77}$ suggested by the boar's arousal by the pheromone of a woman in estrus. Thus, the Gorgon Medusa had porcine attributes - the nose, ears, and tusks of a sow, and the sorceress Circe turned men into boars, for which the antidote was moly, or [h]ómomi. ${ }^{78}$ As the délphax, the pig is named like the dolphin for the "womb," cognate with French Dauphin.

\section{The Lily-mushroom of Ixion's Torment}

An Etruscan mirror explicitly depicts the lily as an analogue of the mushroom. It portrays Ixion bound to the spoked solar wheel, flying in shamanic torment, with a bizarrely-drawn "flower" at his feet. ${ }^{79}$ Again, in view of the beautifully exact engraving of the mirror's subject, the ineptness of the flower's depiction would have displeased the artist's patron, were it not intentional, like the lupine snout on the suckling Hercle. Cook, in his discussion of the mirror, dismissed the "flower" as a meaningless design. ${ }^{80}$ The left bottom of the mirror is lost, but presumably it would have had another version of the "flower," either identical or perhaps as a clue or comment on the extant "meaningless design." There are no meaningless designs on Etruscan mirrors.

Ixion at a banquet with the Olympians upon their magical foods of ambrosia and nectar ${ }^{81}$ tried to rape Hera, but was misled by a hallucinatory look-alike in the persona of the lady Cloud (Nephéle).$^{82}$ Hallucinatory erotic-ecstatic experience at

74. Homeric Hymn to Dionysus (26), 6: in a fragrant cave. Nonnus, Dionysiaca, 9.65: in a gloomy house. Nonnus, Dionysiaca, 14.151: in a dark cellar as the baby called daddy to the skies. Greek houses did not ordinarily have cellars.

75. Euripides, Bacchae, 708-710; Philostratus, Elder, Imagines, 1.14; Nonnus, Dionysuaca, 45.309-310.

76. This etymology accounts for the quantity of the upsilon as long, as in "pig." Ruck, The Great Gods of Samothrace, 394-395.

77. Aristophanes, Acharnians, 729-817; Henderson, The Maculate Muse, 132.

78. Ruck. Dionysus in Thrace, 140-141.

79. Ixion, bound to the spoked wheel, ca. 460-450 BCE, British Museum, inv. no. GR 1900 611.3.

80. Arthur Bernard Cook, Zeus: A Study in Ancient Religion (New York: Cambridge University Press, 1914-1940), 201, fig. 146.

81. Lucian (second century CE), Dialogues of the Gods, 9.

82. Pindar, Pythian Odes, 2.32 et seq.; Pseudo-Apollodorus, Bibliotheke, Epitome, 1.20. 
a divine dinner upon ambrosia and nectar surely implicates the role of an entheogen. The union of Ixion with Cloud resulted in the tribe of centaurs, who sprouted from a rainfall upon the slopes of Mount Pelion, ${ }^{83}$ the mountain ridge that borders the northern edge of the plain of Thessaly, claimed in antiquity along with the Peloponnesus, as one of the original homelands of the Etruscan people. ${ }^{84}$ Aristophanes staged a chorus of Clouds in his parody of Socratic teaching (423 $\mathrm{BCE}$ ), identifying the phallus that was their obligatory costuming for the comic stage as their noses, as they inhaled the nebulous smoke of cannabis that allowed them to get high. ${ }^{85}$

As punishment for his misled delusional rape of Hera, Ixion was bound spread-eagled (or in running-man position ${ }^{86}$ ) to a whirling wheel of fire. Ixion was named as the "mistletoe" (Viscum album ${ }^{87}$ ), which in English is derived as the "urine-twig," 88 cognate with "micturition." He is depicted on an Apulian amphora, bound to his fiery wheel, while Hephaestus with hammer on one side leans upon a tree sprouting the twigs of mistletoe and an Erinys on the other sets the wheel whirling. ${ }^{89}$ Erinyes traditionally afflicted their victims with maddening toxins. ${ }^{90}$ The scene is witnessed by an enthroned Zeus and the rainbow Iris, who is a thematic doublet for the rainy lady Cloud. The botanical persona of Ixion as the urine-twig mistletoe refers to the sanctity of the Amanita muscaria and its potentiated metabolite in urine among the Druids. The motif extends even to the supposedly poisonous urine of toads. ${ }^{91}$ The toad's lascivious eroticism made it a common metaphor for the vulva. ${ }^{92}$ It was often represented with its hind legs spread wide apart to expose its genitals.

The spoked wheel of Ixion's torment is a demonstrable image of the gilled underside of the mushroom's cap as a spoked wheel. From Ixion was descended the race of centaurs, whose leader Chiron possessed vast herbal knowledge, which he taught traditionally to the heroes entrusted to his tutelage as the poison-arrow

83. Diodorus Siculus, 4.12.5.

84. Hellanicus of Lesbos (fifth century BCE), Phoronis (genealogical notices of events from the times of Phoroneus, primordial king of the Peloponnesus), frag. 76.

85. Carl A.P. Ruck. "Aristophanes' Parody of Socrates as a Pothead and the Spartan Warrior Cult of the Wolf," in Seeking the Sacred with Psychoactive Sacraments: Chemical Paths to Spirituality and God, vol. 1, History and Practices, ed. J.H. Ellens (Santa Barbara: ABC-CLIO, 2014): 75-91; Carl A.P. Ruck, "Cannabis, Caves, and Plays," in One Toke to God: The Entheogenic Spirituality of Cannabis, ed. M.J. Estren (Malibu: Cannabis Spiritual Center, 2017), 27-32.

86. Kylix, $c a$. 500 BCE: Ixion, bound to his wheel in running position, Museum of the History of Art, Geneva, inv. no. 5728.

87. Greek [w]ixía, [w]ixós.

88. Sanskrit mehati, cognate with Greek omeích-ein. Carl A.P. Ruck, Blaise Staples, and Clark Heinrich, The Apples of Apollo: Pagan and Christian Mysteries of the Eucharist (Durham: Carolina Academic Press, 2001), 15-40.

89. Saint Petersburg, Hermitage Museum, printed as fig. 146 in Cook, Zeus.

90. Vergil, Aeneid, 7.346 et seq.

91. Adrian Morgan, Toads and Toadstool (Berkeley Celestial Arts, 1996), 10.

92. Hieronymus Bosch, Seven Deadly Sins, Prado, Madrid: superbia with toad over vulva. Wasson. The Wondrous Mushroom, 184 et seq. 
motif of toxic archery. ${ }^{93}$ The Gorgon Medusa, among her other zoomorphic materializations, was a centaur. ${ }^{94}$

The centaurs, as a race of creatures that sprouted from a mountain rainfall and as a tribe of primordial men known as the Lapiths are an equine zoomorphism of the same mushroom motif that yielded the Gorgon Medusa and the bovine anthropomorphism of the cow maiden Io. Io was cited as the sister of the mushroom maiden Mykene, after which the citadel was renamed Mycenae. The Lapiths are named as a primordial race of stones, "sons of the rock." ${ }^{95}$ It is perhaps significant that if Hephaestus is not the deity who provides the wheel for Ixion's torment, the spoked wheel is presented by Athena in her role of Metis-Medusa analogue. ${ }^{96}$

The curiously ineptly depicted "flower" on the Etruscan Ixion mirror was identified by Robert Graves as a mushroom. He suggested that it was the food of centaurs, that they embodied the animism of the psychoactive mushroom. ${ }^{97}$ Wasson had earlier accepted ("he is surely right") and presented Graves' identification in Mushrooms, Russia, and History. ${ }^{98}$ The bizarreness of the depiction, as Wasson reasoned, was its likeness to the fire-drill, the stipe representing the penis, called "mushroom" in Greek, as a stick, drilling into the cap as vulva, with the crosshatching lines on the underside of the cap designating the radiating gills as the teeth of the "comb" of the loom, the vulva as a sacred image, comparable to the male member as phallus. Mushrooms were employed as tinder for the generation of fire as a sexual union. The fire-drill makes Ixion an analogous tradition to Prometheus' theft of fire. Prometheus stole it as a "flower" (ánthos) gathered into the narthex-thyrsus from Hephaestus, and that deity is also the one who chained the Titan to the rock of his torment. ${ }^{99}$

The depiction of the "flower" on the Etruscan mirror has not only deformed the mushroom to illustrate its sexual imagery as a fire-drill, but it has endowed it with an anomalous stem supporting a calyx widening into a trumpet-shaped blossom. The mushroom is morphing into a lily. One such lily is notoriously psychoactive, the Datura, and like the mushroom that was food for centaurs, it bore the folkloric name in Greek as "horse-mad" (hippománes). Ajax "harvested" it as the cause of the delusionary madness that led him to slaughter herds, thinking that they were men. ${ }^{100}$ This lily with the name as dirkaion / kirkaion was also

93. Ruck et al., The Apples of Apollo, 89-92.

94. The earliest depiction of the Medusa: large relief pithos from Thebes, $c a$. 670 BCE, Louvre, Paris, inv. no. CA 795.

95. Latin lapis, "stone," cognate with Greek lepas, "topographical rock," like petra. The patronymic -id suffix in Greek designates "child of."

96. Ares and Hermes apprehend Ixion, before an enthroned Hera, with Athena providing the wheel, Attic red-figure kantharos (Dionysian drinking cup), attributed to the Amphitrite painter, British Museum, London, inv. no. London E155, Beazley archive no. 212127.

97. Robert Graves, Food for Centaurs (Garden City: Doubleday, 1960).

98. Wasson and Wasson, Mushrooms, Russia, and History, 116 et seq.

99. Aeschylus, Prometheus, 7.

100. Sophocles, Ajax, 143; Ruck et al., The Apples of Apollo, 24 et seq.; Ruck, The Son Conceived in Drunkenness, 111, 197. 
involved in the motif of lycanthropy ${ }^{101}$ and with the sorceress Circe as perhaps an analogue of moly, the [h]ómomi or haoma of the Zoroastrian magi priests.

The Ixion mirror surrounds the central episode with a border of trailing wild ivy vine, suggesting that the morphing lily is an analogue to the Dionysian ivy, the prototypic toxic antecedent to the grapevine as the product of human intervention in hybridizing the intoxicating cultivated transmutations of primitive and toxic natural growths. Frequently the vase depictions of the lily from Southern Italy show the blossom as the apparently toxic ${ }^{102}$ bindweed wild morning glory (smilax), with an anomalous head raising from within its funnel and wearing the red Phrygian cap. ${ }^{103}$ The cap derives from the pointed fox snout and the pelt worn by the Bassarides Thracian bacchants, and implies the motif of lycanthropy. ${ }^{104}$ This identifies the lily's flower as the little red-cap, the anthropomorphism of the European folkloric tale of Rotkäppchen and her adventure of initiatory lycanthropy. ${ }^{105}$

A very broad red-figure fourth-century BCE terracotta patera platter from a grave in Apulia depicts the abduction of Persephone with four mushroom-shaped knobs around its rim. ${ }^{106}$ These are clearly not intended as handles since the platter has explicit handles on either side. The central scene is surrounded by a bindweed morning glory vine blossoming with lilies. Two on opposite sides, rising amid the tendrils, are the capped heads of a female. Pliny noted the extraordinary similarity of the morning glory's flower to the lily. ${ }^{107}$

A second-century CE mosaic from a villa north of Rome depicts the winged Gorgon head at its center. ${ }^{108}$ Such Gorgon heads (gorgóneia) were often used as an apotropaic emblem to decorate the entrance hall of houses. The delicate tracery of stems with occasional stylized leaves and flowers filling the area surrounding the Gorgon head sprout from bases midpoint in each quadrant of the central square. Here at the base as if sprouting directly from the ground as well as from the branching and encircling stems are more elaborate and much larger flowers, four of them, arrayed cruciform with the Medusa at its center. They are lilies, complete with three leaves of their calyx. However, the top of each blossom is a

101. Dirke was the wife of the "wolf" Lykos of Thebes. She was a bacchant: Ruck. The Son Conceived in Drunkenness, 129 et seq.

102. Ruck, Dionysus in Thrace, 83: the Grimm fairytale of our lady's little drinking glass identifies the bindweed morning glory as the flower of the Virgin and suggests folkloric knowledge of its intoxicating potential.

103. Red-figure krater, fourth century BCE, Etruscan.

104. Ruck, Dionysus in Thrace, 111 et seq.

105. Carl A.P. Ruck, Blaise Daniel Staples, José Alfredo González, and Marl Alwin Hoffman, The Hidden World: Survival of Pagan Shamanic Themes in European Fairytales (Durham: Carolina Academic Press, 2007), 55-62.

106. Attributed to the Baltimore painter, Art Institute of Chicago. Ruck (ed.), Dionysus in Thrace, 97-99, fig. 6.2 and 6.2a.

107. Pliny, Natural History, 21.11

108. Now installed in the central garden courtyard of the Gardner Museum, Boston. The mosaic was discovered in 1892 in the remains of an ancient villa north of Rome, near the villa of Augustus' wife Livia. It probably was the floor of a bath. The delicate tracery of the interlocking design of stems, flowers, and leaves resembles those of Pompeii around $25 \mathrm{CE}$, but brick stamps indicate that it was laid a century later during the reign of the Emperor Hadrian. 
red rim, spotted with white, and each has a bird anomalously alighting or apparently dancing upon it, as if it were a solid cap, rather than the opened space of the funnel of the lily's trumpet. The birds perhaps identify the flower as their fare, each bird a different species. The lilies appear to be morphing into red mushrooms.

\section{Bibliography}

Allegro, John Marco. The Sacred Mushroom and the Cross: A Study of the Nature and Origins of Christianity within the Fertility Cults of the Ancient near East. London: Hodder and Stoughton, Ltd, 1970.

Bettini, Maurizio. Women and Weasels: Mythologies of Birth in Ancient Greece and Rome, translated by Emlyn Eisenach. Chicago: University of Chicago Press, 2013.

Chantraine, Pierre. Dictionnaire étymologique de la langue grecque. Paris: Klincksieck, 1968-2009.

Cook. Arthur Bernard. Zeus: A Study in Ancient Religion. New York: Cambridge University Press, 1914-1940.

Frisk, Hjalmar. Griechisches etymologisches Wörterbuch. Heidelberg Carl Winters, 19541970.

Graves, Robert. Food for Centaurs. Garden City: Doubleday, 1960.

Grummond, Nancy de. "The Etruscan Mirror." Notes in the History of Art 4, no. 2/3 (1985): 26-35.

Henderson, Jeffrey. The Maculate Muse: Obscene Language in Attic Comedy. New Haven: Yale University Press, 1975.

Kershaw, Kris. The One-eyed God: Odin and the (Indo-) Germanic Männerbünde. Washington, D.C.: Journal of Indo-European Studies, Monograph No. 36, 2000.

Morgan, Adrian. Toads and Toadstool. Berkeley Celestial Arts, 1996.

Ripinsky-Naxon, Michael. The Nature of Shamanism: Substance and Function of a Religious Metaphor. Albany: State University of New York Press, 1993.

Ruck, Carl A.P. "Cannabis, Caves, and Plays." In One Toke to God: The Entheogenic Spirituality of Cannabis, edited by M.J. Estren. 27-32. Malibu: Cannabis Spiritual Center, 2017.

Ruck, Carl A.P. "Duality and the Madness of Herakles." Arethusa 9 (1973): 153-176.

Ruck, Carl A.P. "Mushroom Sacraments in the Cults of Early Europe." NeuroQuantology 14, no. 1 (2016): 68-93.

Ruck, Carl A.P. "The Great God Sabazios and the Crab Dance in Athens." In The Stone Mushrooms of Thrace. Alexandroupoli: EKATAIOS, 2012.

Ruck, Carl A.P. "The Wolves of War: Evidence of an Ancient Cult of Warrior Lycanthropy." Neuroquantology 14, no. 3 (2016): 544-566.

Ruck, Carl A.P. (ed.) Dionysus in Thrace: Ancient Entheogenic Themes in the Mythology and Archaeology of Northern Greece, Bulgaria, and Turkey. Berkeley: Regent Press, 2017.

Ruck, Carl A.P. The Great Gods of Samothrace and the Cult of the Little People. Berkeley: Regent Press, 2017.

Ruck, Carl A.P. The Son Conceived in Drunkenness: Magical Plants in the World of the Greek Hero. Berkeley: Regent Press, 2017.

Ruck, Carl A.P., Blaise Daniel Staples, José Alfredo González, and Marl Alwin Hoffman. The Hidden World: Survival of Pagan Shamanic Themes in European Fairytales. Durham: Carolina Academic Press, 2007. 
Ruck, Carl A.P., Blaise Staples, and Clark Heinrich. The Apples of Apollo: Pagan and Christian Mysteries of the Eucharist. Durham: Carolina Academic Press, 2001.

Ruck, Carl A.P., Mark Alwin Hoffman, and José Alfredo González Celdrán. Mushrooms, Myth, and Mithras: The Drug Cult that Civilized Europe. San Francisco: City Lights, 2011.

Ruck. Carl A.P. "Aristophanes' Parody of Socrates as a Pothead and the Spartan Warrior Cult of the Wolf." In Seeking the Sacred with Psychoactive Sacraments: Chemical Paths to Spirituality and God, vol. 1, History and Practices, ed. J.H. Ellens, 75-91. Santa Barbara: ABC-CLIO, 2014.

Wasson, R. Gordon, Albert Hofmann, and Carl A.P. Ruck. The Road to Eleusis: Unveiling the Secret of the Mysteries. New York: Harcourt Brace, 1978.

Wasson, R. Gordon, Stella Kramrish, Jonathan Ott, and Carl A.P. Ruck. Persephone's Quest: Entheogens and the Origins of Religion. New Haven: Yale University Press, 1995.

Wasson, R. Gordon. The Wondrous Mushroom: Mycolatry in Mesoamerica. New York: McGraw-Hill, 1980.

Wasson, Valentina Pavlovna, and R. Gordon Wasson. Mushrooms, Russia, and History. New York: Pantheon Books, 1957.

Wilson, Peter Lamborn. Ploughing the Clouds: The Search for Irish Soma. San Francisco: City Lights, 1999. 
